\title{
Mandibular Vestibule of the Mouth
}

National Cancer Institute

\section{Source}

National Cancer Institute. Mandibular Vestibule of the Mouth. NCI Thesaurus. Code C160993.

The area of the mouth between the cheeks and the teeth of the mandible. 